\title{
膝関節拘縮に対する鏡視下授動術
}

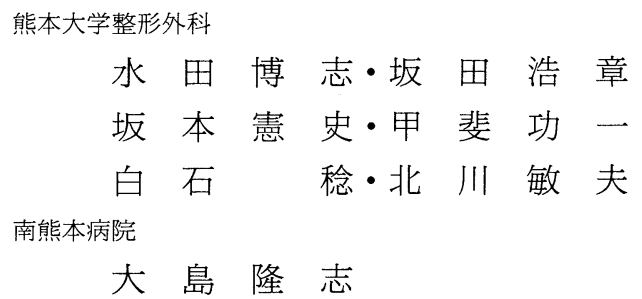

\section{Arthroscopic Mobilization for Knee Contracture}

by

Hiroshi Mizuta, Hiroaki Sakata, Kenshi Sakamoto

Koichi Kai, Minoru Shiraishi and Toshio Kitagawa

Department of Orthopaedic Surgery, Kumamoto University Medical School, Kumamoto

\section{Takashi Oshima}

Minamikumamoto hospital, Kumamoto

Eight patients who were treated by the release of intraarticular adhesions under arthroscopic control for knee contracture following various causes and who were over 1 year postsurgery were reviewed. At follow-up, six patients gained satisfactory motion of the knee joint, while in the remaining two patients results were unsatisfactory. The patient who has extension contracture owing to intraarticular adhesion formation has a good indication of this procedure. It is our impression that best results are obtained in patients with rapidly occurred knee contracture.

\section{は じめに}

膝関節外傷後, あるいは関節手術後の膝関節拘縮は, 臨床上なお重要かつ困難な問題である。従来, 可動域 訓練で改善がみられない膝関節拘縮に対しては, 麻酔 下での徒手的授動術や, Judet 法, Thompson 法など の観血的関節授動術が行われてきた。われわれは，関 節内癒着がその主因と考えられる膝関節拘縮例に対し て, 関節鏡を用いた授動術を行い, 比較的好成績を得 ているので報告する。

$$
\text { 症例 }
$$

症例は術後 1 年以上経過した 8 例 8 膝で, 内 1 例で は 2 度授動術を行った。なお，同時に，内・外側解離 術を行った症例は除いた。症例の詳細は表 1 の通りで ある. 男 5 例, 女 3 例で, 年令は 24 才から 78 才まで,
平均 47.5 オである.治療開始後, 授動術までの期間は, 5 週から 28 週までで, 平均 12.5 週であった。症例は 全例, 可動域訓練で順調な改善のみられなかったもの, および疼痛のために十分な訓練が行えなかったもので ある. 術後観察期間は, 1 年 4 力月から 3 年 7 力月, 平均 2 年 7.4 力月である.

手術は, 全例腰椎麻酔下にて行った。麻酔下に可動 域を調べた後, 外側膝蓋下穿刺により関節鏡を挿入し, 関節内を観察後, 鏡視下に鏡視下手術用ハサミで療着 を剥離した，瘾着が強く, 鏡視が困難な場合は, あら かじめ関節鏡用鈍棒にて癒着をある程度剥離した後, 鏡視下に十分な剥離を行った。 その後, 抵抗があると ころまで徒手矯正を加えた。術後は翌日より可動域訓 練を再開し，原則的に歩行も許可した. 
表 1 症例

\begin{tabular}{|c|c|c|c|c|c|c|c|c|c|}
\hline 症例 & 年令・性 & 診 & 治 & $\begin{array}{l}\text { 固定 } \\
\text { 期間 }\end{array}$ & $\begin{array}{l}\text { 治療開始後 } \\
\text { 授動術まで } \\
\text { の期間 }\end{array}$ & $\begin{array}{l}\text { 術 前 } \\
\text { 可動域 }\end{array}$ & $\begin{array}{l}\text { 術 中 } \\
\text { 可動域 }\end{array}$ & $\begin{array}{l}\text { 現在の } \\
\text { 可動域 }\end{array}$ & $\begin{array}{l}\text { 術 後 } \\
\text { 経過年数 }\end{array}$ \\
\hline 1. & $24 \cdot$ 男 & $\begin{array}{l}\text { 大腿骨内顆 } \\
\text { 開放骨折 }\end{array}$ & 観血的骨接合術 & 3 週 & 11週 & $0^{\circ}-70^{\circ}$ & $0^{\circ}-120^{\circ}$ & FULL & 2 年 4 力月 \\
\hline 2. & 43 -男 & $\begin{array}{l}\text { 内側半月損傷 } \\
\text { 前十字靭帯損傷 }\end{array}$ & $\begin{array}{l}\text { 関節鏡 } \\
\text { ギプス固定 }\end{array}$ & 5 週 & 8週 & $0^{\circ}-50^{\circ}$ & $0^{\circ}-125^{\circ}$ & FULL & 3 年 5 力月 \\
\hline 3. & 55 - 众 & 化膿性関節炎 & 滑膜切除，持続洗浄 & 4 週 & 7週 & $0^{\circ}-20^{\circ}$ & $0^{\circ}-120^{\circ}$ & FULL & 3 年 7 力月 \\
\hline 4. & 45 ・男 & 化膿性関節炎 & 滑膜切除, 持続洗浄 & 3 週 & 5週 & $10^{\circ}-70^{\circ}$ & $10^{\circ}-130^{\circ}$ & FULL & 3 年 5 力月 \\
\hline 5. & 48 - 女 & 脛骨外顆骨折 & ギプス固定 & 8 週 & 10違 & $0^{\circ}-10^{\circ}$ & FULL & FULL & 1 年11力月 \\
\hline 6. & $53 \cdot$ 女 & $\begin{array}{l}\text { 人工膝関節全置換 } \\
\text { 術後 loosening }\end{array}$ & $\begin{array}{l}\text { 人工膝関節再置換術 } \\
\text { 外側縫縮術 }\end{array}$ & 3 週 & 7週 & $0^{\circ}-60^{\circ}$ & $0^{\circ}-100^{\circ}$ & $0^{\circ}-115^{\circ}$ & 1 年10力月 \\
\hline 7. & 78 ・男 & 大腿骨頝部骨折 & $\begin{array}{l}\text { 観血的骨接合術 } \\
(\text { (ノールスピン固定) }\end{array}$ & 8 週 & $\begin{array}{l}\text { 11週 } \\
28 \text { 週 }\end{array}$ & $\begin{array}{l}10^{\circ}-30^{\circ} \\
10^{\circ}-25^{\circ}\end{array}$ & $\begin{array}{l}5^{\circ}-100^{\circ} \\
5^{\circ}-90^{\circ}\end{array}$ & $20^{\circ}-45^{\circ}$ & 3 年 1 力月 \\
\hline 8. & 33 ・男 & $\begin{array}{l}\text { 溙蓋骨開放骨折 } \\
\text { 骨接合術後偽関節 }\end{array}$ & 観血的骨接合術 & 6 週 & 25週 & $0^{\circ}-60^{\circ}$ & $0^{\circ}-70^{\circ}$ & $0^{\circ}-75^{\circ}$ & 1 年 4 力月 \\
\hline
\end{tabular}

結

果

術前の屈曲角度は $10^{\circ}$ から $70^{\circ}$ まで, 平均 $43.9^{\circ}$, 術 中は $70^{\circ}$ から $155^{\circ}$ まで, 平均 $112.2^{\circ}$ であり，授動術に より $10^{\circ}$ から $145^{\circ}$, 平均 $68.3^{\circ}$ の屈曲角度の増加を認め た. 現在の屈曲角度は, $45^{\circ}$ から $160^{\circ}$ まで, 平均 $128.1^{\circ}$ である. 症例 $1,2,3,4,5$ は, 現在正座可能で あり, $115^{\circ}$ の屈曲が可能である人工膝関節再置換術後 の症例 6 とあわせ， 6 例では満足な成績が得られてい る。これに対し，症例 $7 ， 8$ では術前と比べ, 十分な 改善は得られていない. 症例 7 (大腿骨頝部骨折) は, 骨接合術後, 余病のため, 早期のリハビリテーション ができず，膝関節拘縮をきたした。術後 11 週で，授動 術を行い, 術中屈曲は $100^{\circ}$ と, 術前に比べ $70^{\circ}$ の改善 をみた。しかし, 術後, 訓練時の膝痛が強く, 再び拘 縮にいたった。骨接合術後 28 週で, 本人の強い希望も あり, 膝痛の精查とあわせ, 再度授動術をこころみた。 関節内には癒着以外にとくに疼痛の原因と思われるも のはなく, $90^{\circ}$ の屈曲が得られたが, その後も膝痛の訴 えが続き,十分な訓練ができず, 現在可動域は $20^{\circ} \sim 45^{\circ}$ と不満足な結果におわっている。症例 8 (膝蓋骨開放 骨折骨接合術後偽関節）では，偽関節手術前の屈曲角 度は $115^{\circ}$ であった。偽関節手術後 25 週で授動術を行っ たが, 術中の屈曲は術前の $60^{\circ}$ から $10^{\circ}$ しか改善せず, 現在屈曲角度は $75^{\circ}$ である。

良好な結果が得られた代表的症例について述べる。 症例 $2: 43$ 才, 男。

1982 年 12 月 5 日, 階段より転落. 近医受診後, 紹介

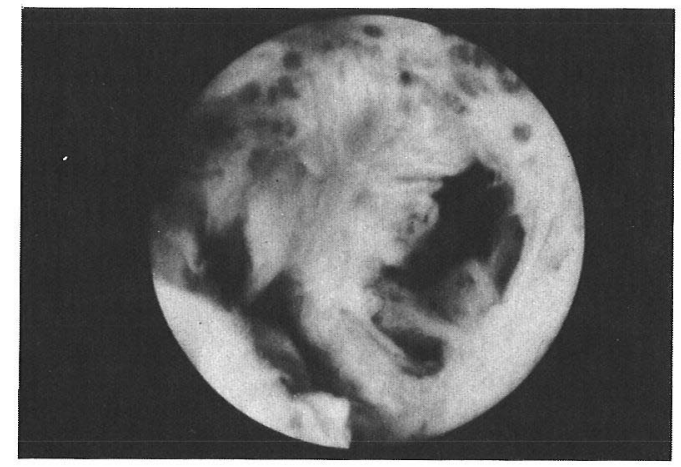

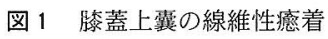

入院となる. 12 月 14 日, 関節鏡にて左膝内側半月辺緑 部損傷および前十字䨣帯損傷の診断で, ギプス固定を うける。1月 17 日ギプス除去し,この時点での可動域 は $5^{\circ} \sim 40^{\circ}$ であった。以後, 可動域訓練を行うが, 膝痛 が強く, 膝蓋骨の運動性も悪く, 可動域の改善がみら れないため，2月 8 日，関節鏡視下授動術を行った。 術前の可動域は $0^{\circ} \sim 50^{\circ}$ であった。膝蓋上囊, 内•外側

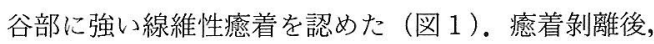
屈曲角度は $125^{\circ}$ と術前に比べ $75^{\circ}$ の改善をみた。その 後, 疼痛は軽減し, 可動域訓練も順調にす寸み, 2 月 15 日, 授動術後 1 週間で退院した。現在, 可動域は $0^{\circ}$ 〜 $160^{\circ}$ で，正座可能である（図 2 ）。

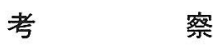

関節鏡を用いた膝関節授動術は, 1982 年, Norman 


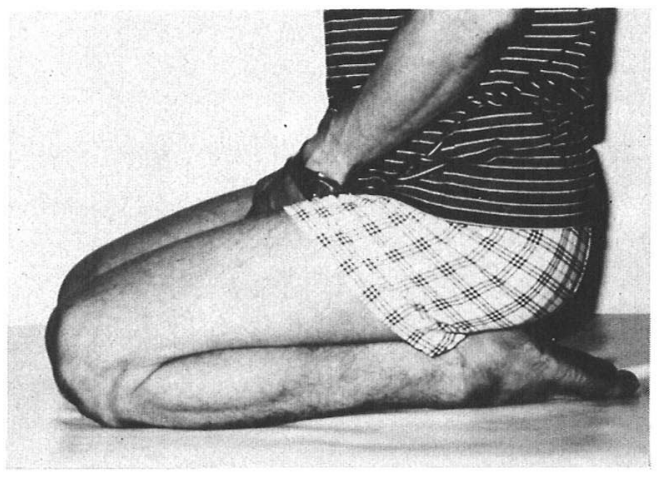

図 2 現在，正座可能である

ら5)により報告され，その後本邦でも，宗広ら ${ }^{4)}$, 佐藤 $ら^{6)}$ ，木村ら ${ }^{2)}$ ，松岡ら ${ }^{3)}$ ，一戸ら ${ }^{1)}$ の報告をみる。

本術式の適応は, 関節内瘾着が主な原因である伸展 拘縮にある．膝関節外傷，関節内手術に伴う拘縮の場 合, 少くとも当初は, その原因は関節内凂着にあり ${ }^{5)}$, また, 山田ら ${ }^{7)}$ は, 下肢のギプス固定後の拘縮における 膝蓋上囊の癒着の重要性を強調している。したがって, これらの拘縮例においては，本術式はいい適応である と考えられる。これに対して, 大腿骨骨幹部骨折後の ような大腿四頭筋の短縮や癒着による関節外拘縮にお いては, 本術式のみでは十分な可動域の改善を得るこ とはできない. 症例 8 では, 関節外拘縮の要素も強く,

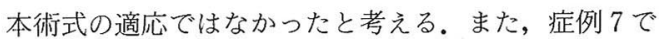
は, 後療法時の疼痛のため, 術中得られた可動域を維 持できず，不満足な結果に終わった。本症例のように 後療法のむずかしい高令者においては，持続硬膜外麻 酔などによる後療法時の除痛に対する配慮4が必要であ ったと反省している.

拘縮発生後, 本術式を行う時期については, 佐藤ら は，拘縮原因発生後 6 力月以内, とくに 3 力月前後に 行った症例では，良好な成績を得たと述べ，また，松 岡 ( $^{3)}$ ，罹病期間が 3 力月以上，あるいは固定期間が 6 週以上の症例では, 結果は不良で, 3 カ月以内に行 うことが好成績につながると述べている。一方, Norman $ら^{5)}$ は, 膝関節手術後 6 力月以内に本術式を行った群 と，6力月以後に行った群とを比較し, 両群の成績に 差はなかったと報告している。しかし, 彼らは, 膝関 節手術後 $2 \sim 3$ 力月の時点で, 可動域の改善が順調に みられない場合は，本術式を行うことをすすめ，本術 式による早期の関節内痖着剥離は, その後の回復をは
やめ,さらに強力な訓練による膝蓋骨の軟骨損傷も減 少させることができると述べている，われわれの症例 においても，治療開始より授動術までの期間が 3 力月 以内である症例 $1 ， 2 ， 3 ， 4 ， 5 ， 6$ では，満足な 結果が得られている。一方, 当初は関節内瘜着が主た る原因である拘縮例においても，経過とともに関節外 要素も増加していくと考えられるが，本術式がいつま で有効であるかは，われわれの少数例の経験では言及 できない. 木村ら ${ }^{2)}$ は, 拘縮発生後 1 年 2 力月で本術式 を行い，良好な成績を得た例を報告し，必ずしも，佐 藤らの述べるように拘縮発生後 6 力月以内とは限定で きないと述べている。この点に関しては，今後の課題 と考える。

本術式は, 従来の麻酔下徒手的授動術や観血的関節 授動術と比較し，1）手技が簡単である，2）膝関節構 成体や大腿四頭筋への侵襲が少ない，3）膝関節内を観 察できる，4)とくに合併症を認めない。などの利点を 有し，可動域訓練で順調な改善がみられず，しかも関 節内瘾着が主たる原因と考えられる症例に対しては, 比較的早期に行われていい方法であると考えている。

$$
\text { ま と め }
$$

鏡視下授動術を行った膝関節拘縮例 8 例について, その成績を検討し，本術式の適応について述べた。

\section{文献}

1）一戸貞文・他：滕関節拘縮に対する鏡視下授動術の 経験。第 7 回東京膝関節研究会 (口演)，東京， 1986.

2）木村郁夫・他：関節鏡を応用した滕関節授動術．整 形外科, $36: 1883-1887,1985$.

3）松岡 彰・他：膝関節拘縮に対する鏡視下授動術の 経験。第 7 回東京膝関節研究会 (口演), 東京, 1986.

4）宗広忠平・他：膝関節手術後関節拘縮に対寸る鏡視 下授動術の経験。関節鏡，9：145-147，1984。

5) Norman, F. R. et al.: Arthroscopic treatment of postoperative knee fibroarthrosis. Clin. Orthop. $166: 165-172,1982$.

6）佐藤圭司・他：関節鏡的授動術の検討．第 33 回東日 本臨床整形外科学会 (口演), 東京, 1984.

7）山田憲吾・他：膝関節硬着に対する滑動装置再建手 術。整形外科, $13: 1-12,1962$.

質 問 福岡大学 王享弘

膝関節拘縮をおこした原因疾患の違いによって，鏡 視下授動術の成績に差があるのかどうか. 
解 答 熊本大学 水田 博志止, 剥離が完全であることを確認できることであ

とくに疾患による成績の差はなかった。

る.

\section{質 問 九州労災病院 井原 秀俊}

われわれは, 関節鏡で観察後, エレバトリウムで半 盲目的に, 膝蓋上包, 側部の谷部, 滕蓋下脂肪体付近 を剝離する方法をとっているが，この方法に比べて， 鏡視下剝離が良い点を教えていただきたい。

\section{解 答 熊本大学 水田 博志}

関節内痖着が強い時は，あらかじめ鈍棒にて盲目的 に剝離後, 鏡視下に剥離を行った。鏡視下にやるメリ
質 問山口大学松岡彰

術後硬膜外麻酔下で早期に動かすことが大切と思い ますがいかがでしょうか.

解 答 熊本大学 水田 博志

今回の症例では全例腰椎麻酔で, 行ったが, 症例 7 を除いて, 翌日からの可動域訓練にとくに支障はなか った。症例によっては，持続硬膜外麻酔も有益と考え る. 